\title{
THE EFFECT OF PRICE, PRODUCT QUALITY, AND ELECTRONIC WORD OF MOUTH (EWOM) ON THE INTENTION TO BUY SUNRIZQ BATIK IN MALAKA MALAYSIA
}

\author{
Abd Rofiq ${ }^{1}$, Joko Suyono \\ dullrofiq@gmail.com¹, joko.suyono@narotama.ac.id ${ }^{2}$ \\ Economics and Business Faculty \\ Management and Marketing Study Program \\ Narotama University Surabaya, Jl. Arif Rahman Hakim 51 Surabaya ${ }^{1,2}$
}

\begin{abstract}
Abstract: Buying interest is the desire that arises from consumers to a product as a result of the consumer's observation of a product. Therefore the purpose of this study is to analyze the extent of the influence of Price, Product Quality, Electronic Word Of Mouth (EWOM) on consumer buying interest. Batik Sunrizq Malacca Malaysia. This research is quantitative research with a sample of 240 respondents. Furthermore, the data were analyzed using multiple linear regression analysis techniques and classical assumption tests. The results of this study indicate that the three hypotheses proposed have a significant and supportive effect.
\end{abstract}

Keywords: Price, Product Quality, Electronic Word of Mouth, Consumer Buying Interest

\section{INTRODUCTION}

\section{Research Background}

This globalization is that batik is no longer limited to art clothes but has developed into the world of fashion, nowadays batik is not only interested in local communities but has been from various foreign countries. This phenomenon has a very positive impact on economic growth in Indonesia, especially for batik artisans themselves, because the level of demand is increasingly high so that many people use it as a business opportunity, one of them in Malaysia, like batik Sunrizq is Indonesian batik exported to Malaysia even though classified as a new business the researchers wanted to analyze whether there were influences from various fields, one of them in the field of influence of Price, Product Quality, and Electronic Wort of Mouth (EWOM) which made Sunrizq batik exist in the Malaysian market especially in the Malacca asean garden area.

From the previous research conducted by (NST \& Yasin, 2014) which states that price (X) has a significant influence on consumer buying interest (Y). Whereas in the research conducted by (Powa, Lapian, \& Wenas, 2018) stating price (X) there is no partial significant effect on consumer buying interest (Y).

This is in line with the research conducted by (Joel, Massie, \& Sepang, 2014) they say that product quality $(\mathrm{X})$ has a significant influence on buying interest $(\mathrm{Y})$. That's a sign that the price and quality of products determine the volume of consumer buying interest. In the research conducted by (Powa et al., 2018), there was no partial significant effect of product quality (X) on consumer buying interest.

In the research conducted by (Hatane Semuel \& Lianto, 2014), their research said that using promotion with Elekronic Word of Mouth had a positive influence on buying interest, seen from the research conducted (Wijaya \& Paramita, 2014) different from previous research, they stated that eWOM had no significant influence.

Based on this background, the problems to be examined are:

1) Is there a positive and significant influence between prices on consumer buying interest?

2) Are there positive and significant influences between product quality and consumer buying interest? 
3) Is there a positive and significant influence between Electronic Word of Mouth (eWOM) on consumer buying interest?

4) Are there positive and significant influences between price, product quality and eWOM on consumer buying interest?

\section{LITERATURE REVIEW AND HYPOTHESIS DEVELOPMENT}

\section{Relationship Between Prices Against Consumer Buying Interests}

According to Kotler and Keller (2017: 340) defines price as the amount of money billed for a product or service, more broadly the price is the amount of value exchanged by consumers for the benefits of having a product or service. Pricing is a very important thing to do in order to attract consumer buying interest. This is in line with the research conducted by Fakhru and Hanifa: (2014) that prices have a significant influence on consumers' buying interest, Greg, et al: (2014) also say the same thing that prices have a significant influence on consumer buying interest. Therefore the proposed hypothesis is as follows:

H1 has a partial influence on buying interest in Sunrizq Batik

\section{The Relationship Between Product Quality and Consumer Purchase Interests}

In the research of Salfina, Kotler and Armstrong (2008), it states that quality is the ability of a product to carry out its functions, that ability includes durability, reliability, accuracy produced, ease of operation and repair and other valuable attributes on the product as a whole, 2018 ). For business people, product quality is very important to note because product quality is one of the important factors to attract consumers' buying interest, this has been examined by Suhaily and Darmoyo (2017) where in their research they stated that product quality has a positive influence on purchasing decisions, and also has a significant influence on customer trust. Guen, Joyce, and Rudy (2018) in their research also stated that simultaneous product quality has a significant influence on consumer buying interest. Therefore the hypothesis proposed is as follows :

H2 Product quality has a partial influence on Sunrizq's Batik buying interest

\section{Relationship Between eWOM with Consumer Buying Interests}

Consumer buying behavior. Recommendations from trusted friends, associations and other consumers have the potential to be more trusted than commercial sources, such as advertisements and salespeople. Mostly, word of mouth occurs naturally, consumers start by talking about a brand that they use to others. Kotler \& Armstrong, (2012: 139) and Electronic Word of Mouth have proven to have a big role in consumer purchasing decisions by influencing consumer choices Word of Mouth is often said to be called viral marketing, a marketing technique used to spread a marketing message from one websites or users to websites or other users, which can create potential exponential growth like a virus. With the description of these experts it can be concluded that eWOM has an important role in delivering product information to consumers. Therefore the proposed hypothesis is as follows:

H3 Electronic Word of Mouth has a partial influence on the interest in buying Batik Sunrizq

\section{Consumer Purchase Interest}

buying interest is the stage of the respondent's tendency to act before the buying decision is actually implemented. Kinnear and Taylor (1995) in Sulistyari (2012: 19). Therefore the proposed hypothesis is as follows:

H4 Price, Product Quality, EWOM, have a simultaneous influence on Purchase interest in Batik Sunrizq 


\section{Research Conceptual Framework}

Based on the objectives and relevant literature, this study proposes a research model of the influence of, Price, Product Quality, Electronic Word of Mouth, and the model

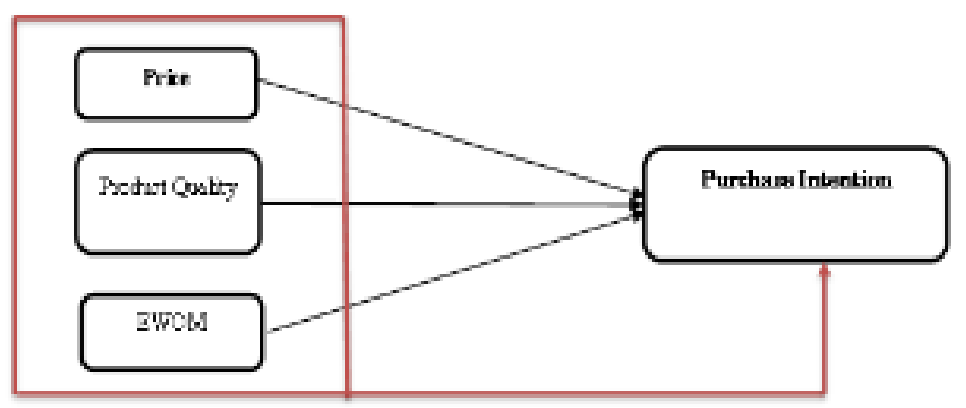

shown in Figure 1.

\section{RESEARCH METHOD}

\section{Types of research}

The type of research used in this study is a correlational quantitative method with a descriptive research approach and verbal analysis.

\section{Population and Sampling}

The population in this study are consumers and non-consumers (who have never bought batik sunrizq) with a sample of 240 respondents

\section{Types, Sources and Data Collection Techniques}

The variable in this study used is the first independent variable (X1) is Price, the second independent variable (X2) is Product Quality, the third independent variable (X3) is Electronic Word Of Mouth and the dependent variable used in this study is buying interest.

\section{Data analysis technique}

1. Test Validity and Reliability

3. Multiple Linear Regression Test

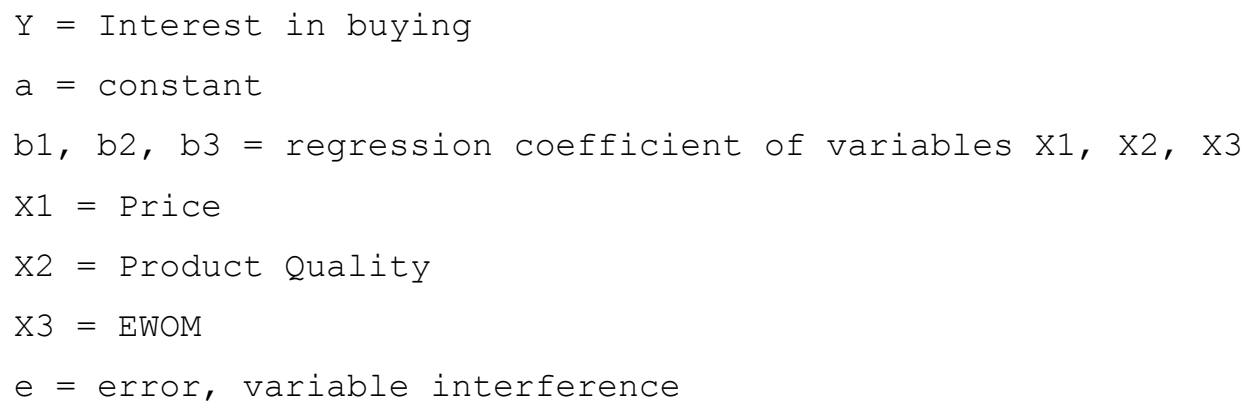

4. Test the Hypothesis 


\section{a. Partial Test (T Test)}

This test aims to examine whether the independent variables (Price, Quality of Products, Electronic Word of Mouth) on the dependent variable (interest in buying) have a partial or separate influence.

\section{b. Test F}

The F test is used to determine the effect of the Batik Sunrizq buying interest process based on Price, Product Quality, and Electronic Word of Mouth.

\section{RESULTS AND DISCUSSION}

Table 1.

Characteristics Customers

\begin{tabular}{|c|c|c|}
\hline Gender & Total & Percent \\
\hline Male & 81 & $33.75 \%$ \\
\hline Female & 159 & $66.25 \%$ \\
\hline Total & 240 & $100 \%$ \\
\hline
\end{tabular}

\begin{tabular}{|c|c|c|}
\hline Work & Total & Percent \\
\hline Students & 50 & $20.80 \%$ \\
\hline Employees & 80 & $33.30 \%$ \\
\hline Businessman & 110 & $45.80 \%$ \\
\hline Total & 240 & $100 \%$ \\
\hline
\end{tabular}

\begin{tabular}{|c|c|c|}
\hline Ages & Total & Percent \\
\hline$<20$ years old & 44 & $18.30 \%$ \\
\hline $21-30$ years old & 52 & $21.70 \%$ \\
\hline $31-40$ years old & 90 & $37.60 \%$ \\
\hline $41-50$ years old & 44 & $18.30 \%$ \\
\hline$>50$ years old & 10 & $4.10 \%$ \\
\hline Total & 240 & $100 \%$ \\
\hline
\end{tabular}

\section{Reliability and validity}

Based on research shows that the cronbanch alpha value is 0.761 which means that it is above the acceptance limit of 0.6 therefore, the research instrument for the relationship between variables shows good consistency and acceptable data. Based on the research value of the correlation index for the relationship between the independent variables (Price, Product Quality, EWOM) and the dependent variable (Purchase Interest) greater than 0.3 and below the significant level of 5\% (0.05). Therefore, the data is considered valid. 
Multiple Analysis Test Results

Table 2.

Results of Multiple Regression Analysis Test

\begin{tabular}{|c|c|c|c|}
\hline Variable & Regression Coefficient & Counted & Sig. \\
\hline Constant & -1.495 & -1.597 & 0.111 \\
\hline Price $(\mathrm{X} 1)$ & 0,049 & 1.128 & 0.26 \\
\hline Product Qulity (X2) & 0,555 & 24.01 & 0 \\
\hline EWOM (X3) & -0.002 & -0.094 & 0.925 \\
\hline F count & & 202,775 & \\
\hline Signifikan & & 0 & \\
\hline $\mathrm{R}$ & & 0,844 & \\
\hline $\mathrm{R} 2$ & & 0,713 & \\
\hline Adjusted Rsquare & & 0,709 & \\
\hline
\end{tabular}

By entering the values obtained from the SPSS calculation above, multiple regression equations can be obtained, namely:

$$
\begin{aligned}
& \hat{Y}=a+b \times 1+b \times 2+b \times 3 \\
& \hat{Y}=-1.495+0,049 \times 1+0,555 \times 2+-0.002 \times 3
\end{aligned}
$$

\section{Constant}

Obtained Y constant value of -1.495 means Consumer Buying Interest (Y) of -1.495 units assumed as Price (X1), Product Quality (X2), EWOM (X3) then Consumer Buy Interest (Y) is 0 desired by independent variable 0 then the approved or dependent variable will be -1495 .

\section{Price coefficient value (X1)}

The price coefficient (X1) is 0.049, increasing the Batik Sunrizq product increases the Price (X1) it will increase Consumer Buying Interest (Y) by 0.049, units. Assuming the value of the Product Quality (X2) and EWOM (X3) equals zero.

\section{Product Quality Coefficient Value (X2)}

The product quality coefficient value (X2) is -0.555 , Batik Sunrizq's added value increases, the Product Quality will increase Consumer Buying Interest (Y) by 0.555 , unit. With the assumption value Price (X1) and EWOM (X3) equals zero.

\section{EWOM (X3) Coefficient Value}

EWOM coefficient value (X3) is -0.002 , Batik Sunrizq's added value increases EWOM (X3), it will increase Consumer Buy Interest (Y) by 0.002 units. With the value of the price assumption (X1) and the quality of the Preoduk (X2) equal to zero

\section{T test}

Price variable (X1) is known that the value of tcount is 1.128 smaller than ttable 1.969654 then $\mathrm{H} 0$ is accepted and Ha is rejected, meaning that Price (X1) does not have a significant effect partially on Consumer Purchasing Interest (Y). This means that the product price does not affect the sales volume of Batik Sunrizq.

Product Quality Variable (X2) is known that the value of tcount is 24.010 greater than ttable 1.969654 then $\mathrm{H} 0$ is rejected and $\mathrm{Ha}$ is accepted. This means that it explains that the better the quality of products perceived by consumers, the more influential the consumers' buying interest in Batik Sunrizq. 
EWOM variable (X3) based on the known value of tcount of -0.094 smaller than $0.05 \mathrm{H} 0$ is accepted and $\mathrm{Ha}$ is rejected means that EWOM (X3) does not significantly influence the Consumer Purchase Interest (Y). This means that it explains that EWOM does not affect the sales volume of Batik Sunrizq.

\section{Test F}

Based on the results of the $F$ test calculation obtained the results of $F$ count 202.775 greater $F$ Table 2.106089 with a sign level of 0,000 smaller $(\alpha) 0.05$, because the probability is smaller 0.05 then $\mathrm{Ha}$ is accepted, meaning the variable Price (X1), Product Quality (X2), and EWOM (X3) simultaneously influence consumer interest in buying (Y). Thus the first hypothesis that the author submits in this study is proven empirically.

\section{DISCUSSION}

Purchasing interest is a consumer's interest in a product by finding additional information (Schiffman \& Kanuk: 2004). According to Rizky \& Yasin (2014) the interest that arises in a buyer is often in conflict with his financial condition. Interest in buying customers is a hidden desire in the minds of consumers. This can be said of the occurrence of consumer buying interest due to several factors that influence it. One that allows the buying interest of consumers, namely the price of a product itself.

The marketing strategy of a product is based on the needs of consumers, with the aim that the business can survive and still maintain its existence. Based on this they (entrepreneurs) try to influence consumers in every way so consumers are interested in buying products or services. This relates to the price the buyer is referring to. According to Kotler and Armstrong (2008) price is the amount of money that customers must pay to obtain a product. And according to Basu Swastha and Irawan the price is the amount of money (plus a few products if possible) needed to get a combination of products and services (Wardani: 2015).

The price of a product is a measure of the value of one's satisfaction with the product he is buying. Someone will dare to pay for a product at a high price if the product exceeds his expectations. In a sense, the price must be in accordance with the product desired by consumers. Surely this refers to the quality of the product, which according to Thamrin Abdullah and Francis Tantri (Wardani: 2015) Product Quality is the overall characteristics and characteristics of an item or service that affects its ability to satisfy expressed or implied needs. Obviously this is a customer-centered definition of quality. Customers have certain needs and expectations. We can state that certain sellers are qualified if their products and services meet or exceed customer expectations.

Companies that can satisfy most customer needs almost all the time are quality companies. Product quality is a priority in the assessment of a product based on physical and service if it is in the form of services.

Over time with sophisticated technological capabilities where all activities can be done with the help of technology. As with product marketing, to compete and keep up with current advancements, it is very important to utilize the technology. For example, Electronic Word of Mouth (EWOM) which can be used as a strategy in introducing products or services to attract consumers.

According to Faza: (2018) Hennig-Thurau, Gwinner, Walsh, and Gremler: (2004)), EWOM is a positive or negative statement made potentially and actually by consumers who have used products or services from a company and can be accessed by many people and institutions through the internet.

According to Kotler (2008) Interest in buying is something that arises after receiving a stimulus from the product he sees, from there arises an interest in buying in order to have it. Consumer buying interest will arise by itself if consumers already feel attracted or give a positive response to what is offered by the seller.

\section{CONCLUSION AND SUGGESTIONS}

\section{A. Conclusion}

Based on the analysis that has been done, some conclusions can be drawn as follows:

1. The results of this study are obtained from the SPSS calculation based on the F test, the calculated

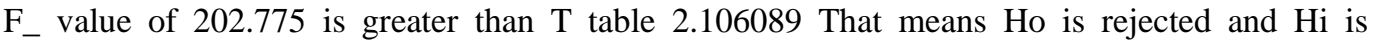
accepted, Price variable (X1), Product Quality (X2), EWOM (X3), simultaneously has a 
significant effect on consumer buying interest (Y). This shows that the fourth hypothesis which reads "Price, Product quality, and Electronic Word of mouth have a significant effect on consumer buying interest" is empirically proven.

2. The results of this study were obtained from the calculation of SPSS based on the test,

a. Price does not partially have a significant effect on consumer buying interest where it is known that the value of tcount is 1.128 smaller than ttable 1.969654 then $\mathrm{H} 0$ is accepted and $\mathrm{Ha}$ is rejected means that Price (X1) does not have a significant effect partially on Consumer Buying Interest (Y). This shows that the first hypothesis which reads "Price has no significant effect on consumer buying interest" is empirically proven.

b. Product quality has a partially significant effect on consumer buying interest where it is known that the value of $\mathrm{t}$ count is 24.010 greater than ttable 1.969654 then $\mathrm{H} 0$ is rejected and Ha is accepted. This shows that the second hypothesis which reads "Product Quality has a significant effect on consumer buying interest" is empirically proven

c. EWOM does not have a significant effect partially on consumer buying interest where the value of t-value of -0.094 is smaller than $0.05 \mathrm{HO}$ is accepted and Ha is rejected means that EWOM (X3) does not have a significant effect partially on Consumer Buying Interest (Y). This shows that the third hypothesis which reads "EWOM does not have a significant effect on consumer buying interest" is empirically proven

\section{REFERENCES}

Aldaning, A. P., \& Fauzi Achmad, W. (2018). The Effect Of Ewom And Hedonic Motivation Toward Buying Interest And Decision. Director, 15(2), 2017-2019. Https://Doi.Org/Https://Doi.Org/10.18551/Econeurasia

Amron, A. (2018). The Influence Of Brand Image, Brand Trust, Product Quality, And Price On The Consumer's Buying Decision Of Mpv Cars. European Scientific Journal, Esj, 14(13), 228. Https://Doi.Org/10.19044/Esj.2018.V14n13p228

Anto, D. (1986). Pengantar Metode Statistik (2nd Ed.). Jakarta: Lp3es.

Ardhianto, T., Nurgiyatna, \& Prasetyo, T. (2013). Aplikasi Pengenalan Batik Indonesia Berbasis Mobile Android. (1), 1-14.

Aritonang, R., \& Lerbin, R. (2007). Riset Pemasaran. Samarinda: Ghalia Indonesia.

Brata, B. H., Husani, S., \& Ali, H. (2017). The Influence Of Quality Products, Price, Promotion, And Location To Product Purchase Decision On Nitchi At Pt. Jaya Swarasa Agung In Central. Saudi Journal Of Business And Management Studies, 2(5), 507-512. Https://Doi.Org/10.21276/Sjbms

Galih, B. (2009). 2-Oktober-2009-Unesco-Akui-Batik-Sebagai-Warisan-Dunia-Dari-Indonesia. Retrieved From Https://Nasional.Kompas.Com/Read/2017/10/02/08144021/2-Oktober-2009-Unesco-AkuiBatik-Sebagai-Warisan-Dunia-Dari-Indonesia

Ghozali, I. (2005). Aplikasi Analisis Multivariate Dengan Program Spss (3rd Ed.). Semarang: Undip.

Ghozali, I. (2009). Aplikasi Analisis Multivariate Dengan Program Spss (4th Ed.). Semarang: Undip.

Hatane Semuel, \& Lianto, A. S. (2014). Analisis Ewom, Brand Image, Brand Trust Dan Minat Beli Produk Smartphone Di Surabaya. Jurnal Manajemen Pemasaran, 2(2), 1-7. Https://Doi.Org/10.9744/Pemasaran.8.2.47-54

Joel, G., Massie, J. D. D., \& Sepang, J. L. (2014). Pengaruh Motivasi, Persepsi Harga, Dan Kualitas Produk Terhadap Minat Beli Konsumen Sepeda Motor Matic Merek Yamaha Mio Di Kota Manado. Jurnal Emba, 2(3), 1463-1472.

Kotler, \& Keller. (2012). Manajemen Pemasaran (12th Ed.). Jakarta: Erlangga.

Lestari, P. (2017). Pengaruh Kualitas Produk Dan Harga Terhadap Kepuasan Konsumen Dan Dampaknya Terhadap Kepercayaan Konsumen Teh Botol Sosro. 22-70.

Marjudin. (2018). Kemenperin Akui Potensi Pasar Ekspor Batik Sangat Besar. Retrieved From Https://Www.Indopremier.Com/Ipotnews/Newsdetail.Php?Jdl=Kemenperin_Akui_Potensi_Pasar_ Ekspor_Batik_Sangat_Besar\&News_Id=90763\&Group_News=Ipotnews\&News_Date=\&Taging_S ubtype $=$ Tekstil $\&$ Name $=\&$ Search $=$ Y_General $\& Q=$ Tektil, Industri Tekstil $\&$ Halaman $=1$

Nst, M. F. R., \& Yasin, H. (2014). Pengaruh Promosi Dan Harga Terhadap Minat Beli Perumahan Obama Pt. Nailah Adi Kurnia Sei Mencirim Medan. Jurnal Manajemen \& Bisnis, 14(02), 561-565. 
Powa, G. A., Lapian, S. L. H. V. J., \& Wenas, R. S. (2018). Pengaruh Kualitas Produk, Harga Dan Word Of Mouth Terhadap Minat Beli Konsumen Handphone Pada Mahasiswa Feb Unsrat. 6(3), 11881197.

Sari, D. P., \& Nuvriasari, A. (2018). Pengaruh Citra Merek, Kualitas Produk Dan Harga Terhadap Keputusan Pembelian Produk Merek Eiger (Kajian Pada Mahasiswa Universitas Mercu Buana Yogyakarta). Jurnal Penelitian Ekonomi Dan Bisnis, 3(2), 73-83.

Simamora, B. (2011). Memenangkan Pasar Dengan Pemasaran Efektif Dan Profitabel. Jakarta: Pt. Gramedia Pustaka Utama.

Sindunata, I., \& Wahyudi, B. A. (N.D.). Pengaruh E-Wom (Electronic-Word-Of-Mouth) Terhadap Keputusan Pembelian Di Agoda.Com. (2010), 128-138.

Sugiyono. (2013). Metode Penelitian Kuantitatif Kualitatif Dan R\&D. Bandung: Alfabeta.

Suhaily, L., \& Darmoyo, S. (2017). Effect Of Product Quality, Perceived Price And Brand Image On Purchase Decision Mediated By Customer Trust (Study On Japanese Brand Electronic Product). Jurnal Manajemen, 21(2), 179-194. Https://Doi.Org/10.24912/Jm.V21i2.230

Tjiptono, F., \& Chandra, G. (2012). Pemasaran Strategik. Yogyakarta: Andi.

Torlak, O., Ozkara, B. Y., Tiltay, M. A., Cengiz, H., \& Dulger, M. F. (2014). The Effect Of Electronic Word Of Mouth On Brand Image And Purchase Intention : An Application Concerning Cell Phone Brands For Youth Consumers In Turkey Eskisehir Osmangazi University University Of Nevada. Journal of Marketing Development And Competitiveness, 8(2), 61-68. Https://Doi.Org/10.1108/02634501211231946

Wijaya, T., \& Paramita, L. (2014). Pengaruh Electronic Word Of Mouth ( Ewom ) Terhadap Keputusan Pembelian Kamera Dslr. Econimics And Business, 9(Sancall), 12-19. Retrieved From Http://Repository.Uksw.Edu/Handle/123456789/5668

Sindunata, I., \& Wahyudi, B. A. (N.D.). Pengaruh E-Wom (Electronic-Word-Of-Mouth) Terhadap Keputusan Pembelian Di Agoda.Com. (2010), 128-138.

Utami, R.P \& Saputra, H. Pengaruh Harga Dan Kualitas Produk Terhadap Minat Beli Sayuran Organik Di Pasar Sambas Medan, Universitas Negeri Medan (2017).

Faza, M. Aqshat, Pengaruh Electronik Word of Mouth Terhadap Minat Beli Melaluicitra Merk (Studi Pada Smartphone Xiomi di kota Yogyakarta), Universitas Yogyakarta, 2018

Wardani,H. Sri, Pengaruh Kualitas Produk dan Harga Terhadap Minat Beli Konsumen Muslim Pada Jaziah Boutique Tlogo Semarang Universitas Islam Negeri Walisongo 2015

Kotler And Keller (2012) Manajemen Pemasaran. 12th Edn. Jakarta: Erlangga.

Sugiyono (2013a) Metode Penelitian Kuantitatif Kualitatif Dan R\&D. Bandung: Alfabeta.

Tjiptono, F. (2006) Manjemen Jasa. Pertama. Yogyakarta: Andi.

Tjiptono, F. And Chandra, G. (2012) Pemasaran Strategik. Yogyakarta: Andi.

Ghozali, I. (2012) Aplikasi Analisis Multivariate Dengan Program Ibm Spss. Yogyakarta: Universitas Diponegoro. 